\title{
Spatial distribution for diarrhea hospitalization in São Paulo State
}

Fernanda Pires Cecchetti Vaz 1

Luiz Fernando Costa Nascimento 2

1,2 Departamento de Medicina. Universidade de Taubaté. Av. Tiradentes, 500. Taubaté. São Paulo, SP, Brasil. CEP: 12.030-180. E-mail: luiz.nascimento@pq.cnpq.br

\begin{abstract}
Objectives: to identify spatial pattern on hospitalization rates of children with diarrhea in the counties in São Paulo State.

Methods: ecological and exploratory study on hospitalized data of children with diarrhea under the age of four in 2008 and 2012, the IDH mothers with low schooling level and children living with a low income less than half minimum wage were obtained from Datasus and inserted into digital map of the counties in São Paulo State. Moran's global index (I) and Pearson's coefficients correlation and thematic maps of hospitalization rates of 1,000 children, Moran maps and kernel map were calculated.

Results: there were 34, 802 hospital admissions, with an average rate of 4.7 hospitalizations / 1,000 children ( $S D=7.2)$. Hospitalization rates were correlated only with schooling $(r=0.09, p<0.05)$. Moran's index for hospitalization rate was $I=0.31(p<0.01)$. The thematic map of the hospital admission rates showed a cluster of counties in the west of the State; the kernel map showed a higher density of hospitalization in this region and the Moran map identified 57 counties which deserve attention.

Conclusions: the results provide subsidies for the counties and regional managers to implement measurements aiming to reduce these rates.
\end{abstract}

Key words Diarrhea, Spatial analysis, Child health, Geographic information system 


\section{Introduction}

Diarrheal disease is still a severe public health problem and is responsible for the death of 1.5 million of children under the age of five in the world yearly; it is the second leading cause of mortality in this age group, especially in emerging countries. ${ }^{1}$ The incidence and the mortality of diarrheal diseases are more prevalent until the child's first year of life, afterwards these numbers tend to decrease. ${ }^{2}$ Reports at the Departamento de Informática do Sistema Único de Saúde (The Information Department of the National Health System) (Datasus) show that in Brazil in 2013 more than 60,000 children up to four years of age were hospitalized due to diarrhea were registered and 88 deaths occurred. These hospitalizations, as well as social cost, totaled more than R $\$$ 20 million reais. ${ }^{3}$ Studies estimate that about onethird of the Brazilian pediatric hospital beds are occupied by children with diarrheal diseases. ${ }^{4}$

Infectious diarrhea is associated with infant morbidity and mortality and is considered a frequent syndrome 5 and places in bad condition to live and schooling are also related to a high incidence of hospitalizations due to diarrhea. 6

Spatial analysis is a great importance for the public health since it helps in the diagnosis and the planning in the affected areas through the geographic characteristic of the disease. 6 This tool has been used in several types of studies in varied themes in the pediatric area, such as the spatial analysis of hospitalizations due to pneumonia and burns in Mato Grosso State, 7 in the distribution of newborns with low birth weight, 8 in neonatal mortality, ${ }^{9}$ and other themes for the interest in public health, such as fatal victims in traffic accidents 10 and the identification of risky areas for schistosomiasis mansoni. ${ }^{11}$

The objective of this study is to identify the spatial patterns of hospitalization due to diarrhea in children 0 to 4 years old in the counties in São Paulo State, between 2008 and 2012.

\section{Methods}

An exploratory ecological study was developed with hospitalization data due to diarrhea in children 0 to 4 years of age, living in counties in São Paulo State. The data were obtained from the Datasus, ${ }^{3}$ using the CID-10 morbidity list: "Diarrhea and gastroenteritis of infectious presumed origin", and inserted in a digital map of the counties in São Paulo State obtained from the Instituto Brasileiro de Geografia e Estatísticas (IBGE, 2014)12 (The Brazilian Institute of Geography and Statistics). The study period was from January 1st, 2008 to December 31st, 2012.

The data were collected from hospitalization cases due to diarrhea from the population of this age group and then rates were created for 1,000 children. The Moran index was calculated with its respective $p$-value. This index varies from -1 to 1 , values close to 1 indicate positive autocorrelation, thus, similarity between nearby counties, and negative values indicate that this similarity does not occur. Values closer to zero indicate the absence of significant correlation. In addition to the local Moran index, the local Moran index was used, and so the main neighborhood was by contiguity. 13

Some variables for this study were obtained from the Datasus, ${ }^{14}$ such as demographic and socioeconomic data, although all of them were from 2010. The variables are: percentage of children 0 to 4 years old living in a situation of a low income less than $1 / 2$ minimum wage; Gini index which evaluates the income distribution level and inequality, varying from 0 (absence of inequality) to 1 (maximum inequality); percentage of the population with water supply, basic sanitation and waste collection; maternal schooling (number of women aged 15 years or more do not have an education or have incomplete elementary schooling); thus, the last variable was created for 1,000 children up to 4 years of age. The İndice de Desenvolvimento Humano (IDH) (The Human Development Index) of the counties were also obtained by the Programa das Nações Unidas para o Desenvolvimento (PNUD) (United Nations for the Development Program) portal.15

The global Moran indices for these values and the Pearson's coefficients correlation, measure the degree and the direction (positive or negative) of the correlation between two variables were calculated. The thematic maps were developed with the hospitalization rates due to diarrhea, and the thematic maps of the schooling and low income variables. The local Moran map was also built. This map is built with the data obtained from the Moran diagram which contains four quadrants, and in quadrant 1 are the counties with high rates and that are surrounded by counties also with high rates and they should be the object of attention by the managers of the counties and regional; quadrant 2 contains the counties with low rates surrounded by counties also with low rates, having a low priority. The kernel maps were also built obtaining through an estimator with 150 columns, quartic function, calculation of density and adaptive radius. 13 This map identifies regions of high densities of outcome occurrence, which in the case of this study are: hospitalization rates due to diarrhea, places with low IDH, places with high Gini 
index, places with a high proportion of mothers with incomplete elementary schooling, and places with a high percentage of children living in situation of low income less than $1 / 2$ minimum wage.

The TerraView 4.2.2 program was used for spatial analysis and the statistical significance was $p<0.05$.

The maps and tables are all referred to the hospitalization rate due to diarrhea in children aged 0 to 4 years (per thousand children), in the counties São Paulo State between 2008 and 2012.

\section{Results}

In the 646 counties in São Paulo State, 34,802 hospitalizations due to diarrhea in children under the age of 4 were reported in the period of 2008 to 2012. The mean hospitalization rate is 4.7 cases / 1,000 children up to four years of age $(\mathrm{SD}=7.2)$ with a minimum of 0.00 and a maximum of 51.83 .

The variables are indicated in Table 1 with the mean, standard deviation, minimum and maximum values, thus are low income (percentage of children from 0 to 4 years old living with families with an income less than $1 / 2$ minimum wage), the IDH, percentage of the population with water supply, basic sanitation and waste collection (data from 2000); maternal schooling (number of women aged 15 years or more who do not have an education or have incomplete elementary schooling).

By Pearson's correlation showed that the hospitalization rates were positively and significantly correlated with the proportion of mothers with incomplete elementary schooling $(\mathrm{r}=0.09, \quad p<0.05)$ and were not significantly correlated with the IDH and income variables. This shows that the greater the proportion of mothers with less schooling, the higher the hospitalization rate due to diarrhea in children.

Figure 1 indicates the spatial distribution of hospitalization rates due to diarrhea in São Paulo State. The analysis of this figure allows to identify the counties with a high hospitalization rate due to diarrhea, showing a cluster of counties in the extreme west of São Paulo State, and the counties with lower rates are located in the Vale do Paraíba and the North Coast. The Moran index (I) presented a value $\mathrm{I}=0.31(p<0.01)$, indicating a positive spatial autocorrelation.

The Local Moran map represented by Figure 2, identified that 57 counties are located in the quadrant 1 (High), thus, these counties have high rates and are also surrounded by counties with high rates, having a high priority of intervention. On the other hand, the counties that are in the quadrant 2 (Low) have low rates and are also surrounded by low rates, having lower priority. Municipalities that have high rates and are surrounded by others with low rates, or counties that have low rates and are surrounded by high rates do not have priority defined by the program used, and therefore are defined as Nonsignificant (NS).

Figure 3 demonstrates the Kernel map using the Kernel density, showing that in the west side of São Paulo State are located the counties with the highest density of hospitalization rates due to diarrhea, which coincide with Figure 2.

The Kernel map of the Gini index showed that the highest densities are found in the metropolitan area in São Paulo and in the North Coast. The same geographic pattern was found on the Kernel map the percentage of children up to 4 years of age living with an income of less than $1 / 2$ minimum wage. For the proportion of mothers with incomplete

\section{Table 1}

Descriptive analysis with mean, respective standard deviations, and minimum and maximum values in the variables of the study, São Paulo State, 2008 to 2012.

\begin{tabular}{lcc}
\hline Variables & $\overline{\mathbf{X}} \pm$ SD & Min - Max \\
\hline IDH low income (\%) & $36.24 \pm 11.62$ & $9.12-77.83$ \\
Sanitation (\%) & $0.74 \pm 0.03$ & $0.64-0.86$ \\
Water (\%) & $98.72 \pm 4.49$ & $36.66-100.00$ \\
Waste (\%) & $98.72 \pm 4.49$ & $36.66-100.00$ \\
Low maternal schooling & $98.72 \pm 4.49$ & $36.66-100.00$ \\
(Rate / 1,000 inhab) & $10.76 \pm 2.15$ & $4.63-18.42$ \\
Gini Index & $0.46 \pm 0.06$ & $0.33-0.68$ \\
\hline
\end{tabular}

IDH= Human Development Index. 
elementary schooling, the map presented a high density in the metropolitan region in São Paulo, the North Coast and also in the North and Northwest Region (Figure 4). These distributions do not coincide with the density presented in the Kernel map of hospitalization rates due to diarrhea.

The schooling variable showed spatial dependency, with $\mathrm{I}=0.20(p<0.01)$; however, the region where there are high rates of low schooling does not coincide with the region with high hospitalization rates due to diarrhea. Low income presented a positive spatial autocorrelation with $\mathrm{I}=0.51(p<0.01)$, and the counties with the highest proportion of children living with low income are concentrated in the South region in São Paulo State (Vale do Ribeira) and in the Vale no Paraíba. For the IDH, the spatial autocorrelation was not verified with $\mathrm{I}=0.001(p=0.36)$. The thematic maps of these variables were not shown.

Figure 1

Thematic map of the distribution of hospitalization rates due to diarrhea per 1,000 children aged 0 to 4 years old, according to the counties, São Paulo State, 2008 to 2012.

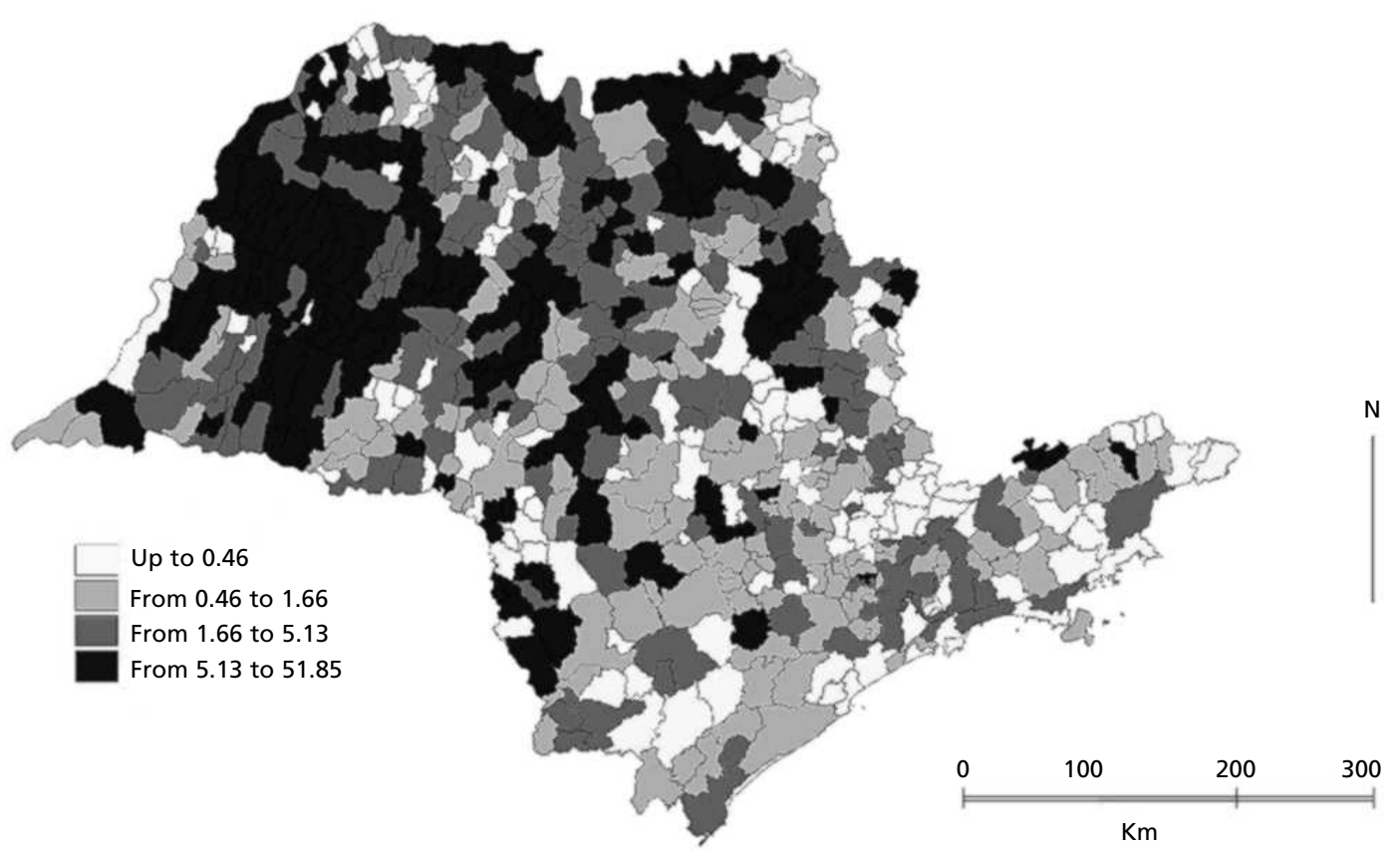


Figure 2

The Moran map on hospitalization rate due to diarrhea per 1,000 children aged 0 to 4 years, according to the priority of the intervention: high, low and non-significant (NS), São Paulo State, 2008 to 2012 ..

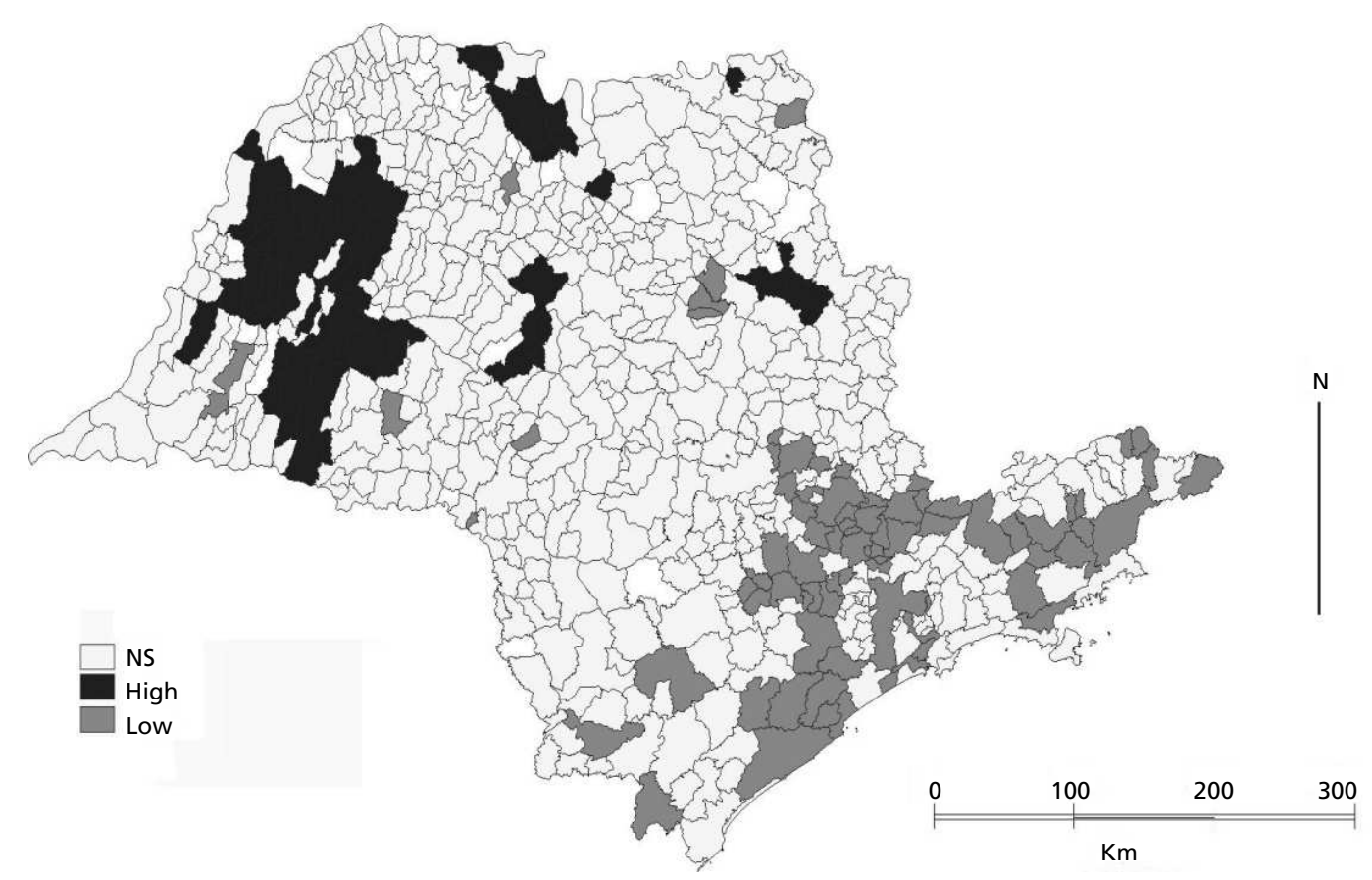

Figure 3

The Kernel density map of hospitalization rates due to diarrhea per 1,000 children aged 0 to 4 years, in São Paulo State, 2008 to 2012.

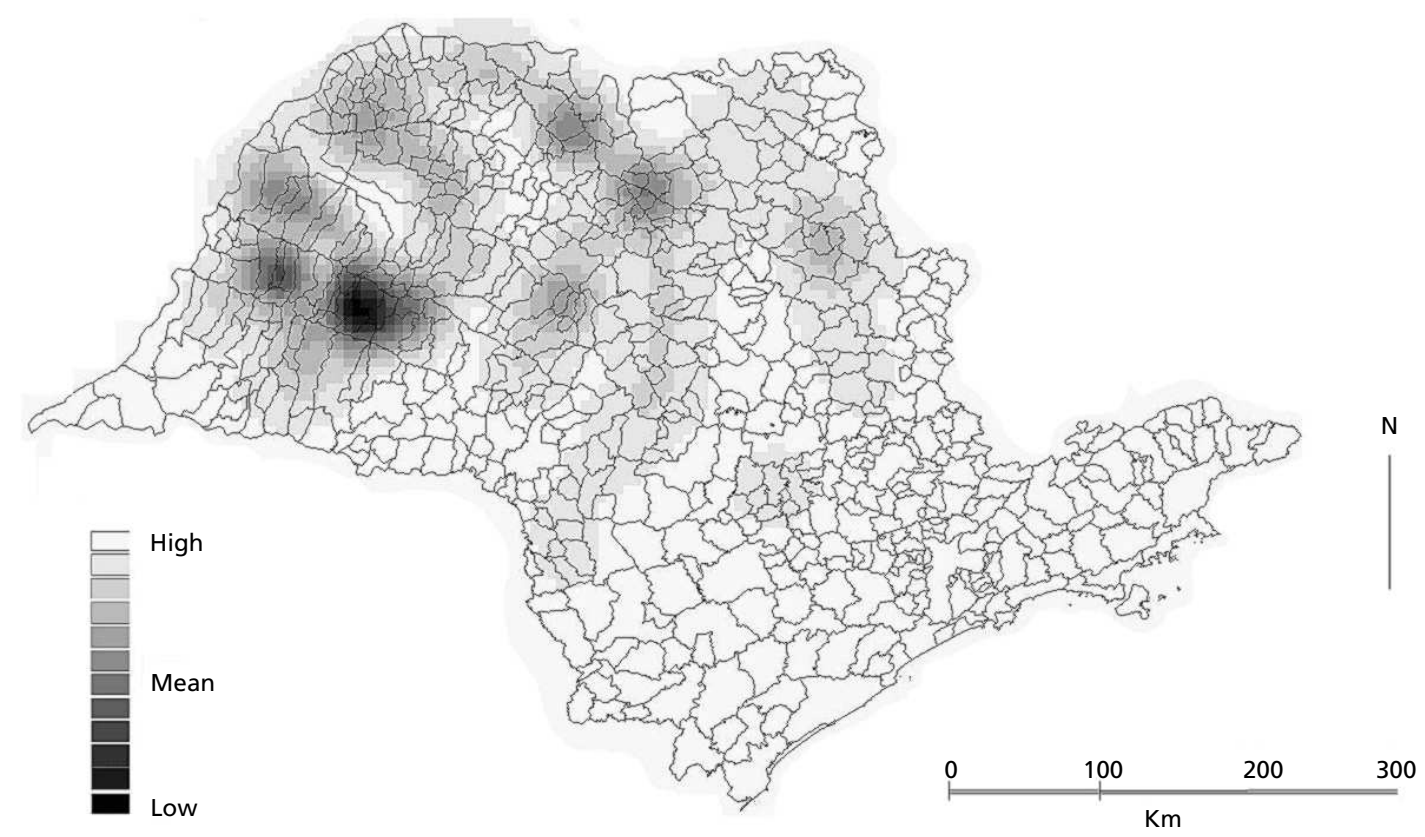




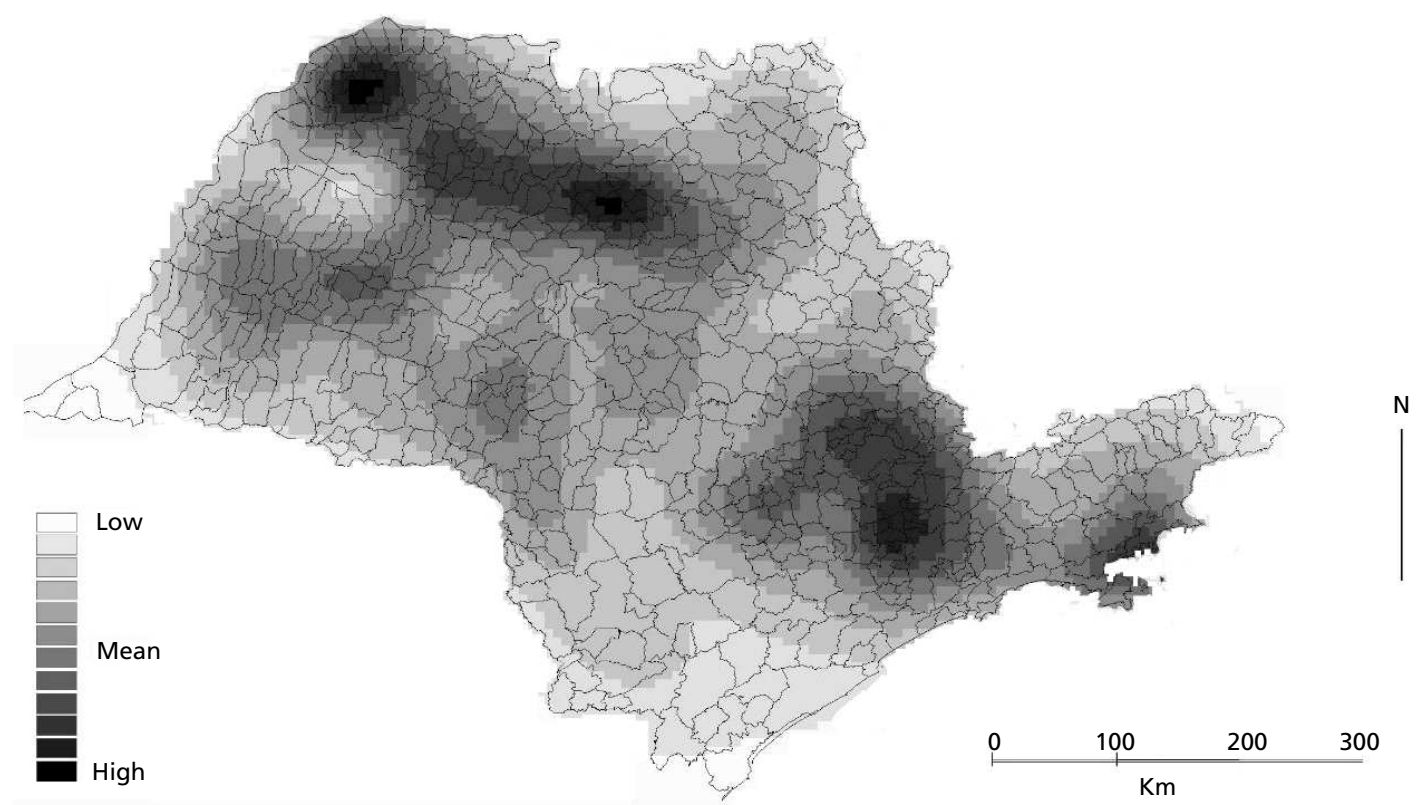

\section{Discussion}

This study allowed to identify the presence of the spatial clusters for the hospitalization rate due to diarrhea in children aged 0 to 4 years of age in the counties located in the West region of São Paulo State between 2008 and 2012; it was possible to correlate positively with maternal schooling and to identify counties that deserve the attention of county and regional managers.

Victora et al.16 found a positive correlation between hospitalization rates due to diarrhea and low maternal schooling, thus, maternal schooling has an independent effect of other socioeconomic factors 16 and is the most frequent occurrence among children whose mothers have little or no schooling. 17

Other studies show that maternal schooling presents a direct relation to the quality of care offered to the children, specifically about the prevention of gastroenteritis, such as hygiene, immunization and breastfeeding, 18,19 thus, the interruption of exclusive breastfeeding up to 6 months of age increases the risk of acquiring infectious diarrheal diseases.4,20 The relation also suggests a greater ignorance about the transmission of diarrheal disease through the mothers. 21

In addition, maternal schooling is related to the capacity for apprehension of knowledge provided by the health professionals, knowledge that collaborate in preventing childhood diarrhea. 22 The difficulty to understand educational activities related to a few years of maternal studying can also be considered as an influence on the children's sickness due to diarrheal diseases. 23

Joventino et al. 23 showed that a monthly family income equal to or less than a minimum wage is a risk factor for helminthiases and thus, higher income allows a better living condition, such as basic sanitation, better housing and easier access to personal hygiene and home care products, and better ways to treat water. ${ }^{23}$ Although diarrhea is normally associated to poor conditions and a family income is significant for its prevalence, 24,25 this present study did not identify a significant correlation between the income variable and the diarrhea rates. 23

There was also no significant correlation between water supply, basic sanitation and the diarrhea rate, this can be due to the fact that the data collected are from the year 2000 and the percentage to supply is high with a mean of $98.72 \%$ coverage. The absence of the correlation may also have occurred because this is an ecological study which hinders the knowledge of the quality of water that each individual has access to. Despite this, studies show that positive changes in expansion of the 
coverage in the public water supply service in São Paulo city justified by part, a decline in the prevalence of child diarrhea. ${ }^{17}$

The IDH was also not a data that presented a positive correlation with the diarrhea rates, possibly because it is not an ideal indicator and reliable to the reality of the counties, since it is an average of economic values of longevity and education. Nevertheless, it is a widely used indicator for measuring the quality of life. 26

The fact that the Kernel maps do not coincide among the variables and the hospitalization rates due to diarrhea can be explained by the fact that this study only evaluates hospitalizations due to diarrhea, considering only the most severe cases. This does not mean that the occurrence of diarrhea, either untreated and treated as outpatients may not be more prevalent in areas with high Gini index, low IDH, high proportion of mothers with incomplete elementary schooling, and high percentage of children living with an income less than $1 / 2$ minimum wage

Oliveira and Latorre 27 identified a reduction in the tendency of hospitalizations and deaths due to diarrhea in children under one year of age from 1995 to 2005 in Brazil and especially in 13 capitals; Meneguesi et al.28 in a 10 year study (2003 to 2012) in Brasilia, DF also observed a reduction in morbidity and mortality in children under 10 years of age with a great reduction in the under 1 year old age group. This reduction may be due to rotavirus vaccination introduced in the Programa Nacional de Imunização (PNI) (The National Immunization Program) in March 2006, mainly in the 0-36 months

\section{References}

1. United Nations Children's Fund (UNICEF)/World Health Organization (WHO) [Internet]. Diarrhoea: Why children are still dying and what can be done. New York; 2009. [acesso em 10 fev 2015]. Disponível em: http://whqlibdoc.who.int/publications/2009/9789241598415_eng.pdf

2. World Gastroenterology Organization (WGO). WGO practice guideline: acute diarrhea. Munich, Germany: World Gastroenterology Organization; 2008. 28 p.

3. Brasil. Ministério da Saúde. Departamento de Informática do SUS - DATASUS, Informações de saúde. Epidemiológicas e morbidade - Brasil. [acesso em $26 \mathrm{fev}$ 2015]. Disponível em: http://tabnet.datasus.gov.br/cgi/ deftohtm.exe?sih/cnv/nrsp.def

4. Sergio JV, Ponce de Leon AC. Analysis of mortality from diarrheic diseases in under-five children in Brazilian cities with more than 150,000 inhabitants. Cad Saúde Pública. 2009; 25: 1093-102. age group in 2007-2011 period, a significant reduction mainly in the $\mathrm{G} 1$ genotype circulation. ${ }^{29}$

This present study present some limitations such as being performed with secondary data that even from official sources such as the Datasus may not correspond to actual data, in addition to the underreporting and notification errors. Even though, reinforcing what has already been explained there may be diagnostic errors, cases of diarrhea in which there might have not been any hospitalization (outpatient treatment with oral replacement serum), hospitalizations by health insurance that are not included in the SUS database. It was also not possible to study other factors because of the lack of information on maternal breastfeeding and hygiene conditions, although these values are better studied in individual, non-population based studies as this present study. Moreover, because this is an ecological study, it is not possible to identify causality,or in other words, it cannot be stated, for example, that hospitalized children due to diarrhea are those whose mothers have low schooling level.

The importance of this study is to identify spatial clusters in counties with considerable hospitalization rates due to diarrhea in children 0 to 4 years old, and to demonstrate a significant correlation between these hospitalizations and maternal schooling. This makes it possible to draw attention to and provide subsidies to counties and regional managers to implement policies aiming to reduce and even abolish these hospitalization rates for diarrheal diseases, as well as reducing mortality in the counties in São Paulo State.

5. Bittencourt AS, Leal MC, Santos MO. Hospitalizações por diarreia infecciosa no estado do Rio de Janeiro. Cad Saúde Pública. 2002; 18 (3): 747-54.

6. Oliveira FJP, Nascimento LFC. Análise espacial da distribuição de doenças diarreicas nos municípios do Vale do Paraíba Paulista. Rev Ambient Água. 2009; 4: 115-23.

7. Nascimento LFC, Medeiros APP. Admissions due to pneumonia and biomass burning: a spatial approach. J Pediatr (Rio J). 2012; 88 (2): 177-83.

8. Nascimento LFC, Costa TM, Zöllner MSAC. Spatial distribution of low birthweight infants in Taubaté, São Paulo, Brazil. Rev Paul Pediatr. 2013; 31 (4): 466-72.

9. Almeida MCS, Gomes CMS, Nascimento LFC. Spatial analysis of neonatal mortality in the state of São Paulo, 2006-2010. Rev Paul Pediatr. 2014; 32 (4): 374-80.

10. Souza VR, Cavenaghi S, Alves JED, Magalhães MAFM. Análise espacial dos acidentes de trânsito com vítimas fatais: comparação entre o local de residência e de ocor- 
rência do acidente no Rio de Janeiro. Rev Bras Estud Popul. 2008; 25 (2): 353-64

11. Cardim LL, Ferraudo AS, Pacheco STA, Reis RB, Silva MMN, Carneiro DDMT et al. Análises espaciais na identificação das áreas de risco para a esquistossomose mansônica no município de Lauro de Freitas, Bahia, Brasil. Cad. Saúde Pública. 2011; 27 (5): 899-908.

12. Brasil. Instituto Brasileiro de Geografia e Estatística (IBGE). Download. [acesso em 6 mar 2015]. Disponível em:

http://downloads.ibge.gov.br/downloads_geociencias.htm.

13. Câmara G, Carvalho MS, Cruz OG, Correa V. Análise de dados de área [acesso em 6 mar 2015]. Disponível em http://www.dpi.inpe.br/gilberto/livro/analise/cap5-areas.pdf

14. Brasil. Ministério da Saúde. Departamento de Informática do SUS - DATASUS, Informações de saúde. Demográficas e socioeconômicas - Brasil [acesso em 13 mai 2015]. Disponível em http://www2.datasus.gov.br/DATASUS/ index.php?area $=0206$

15. Organização das Nações Unidas (ONU) Programa das Nações Unidas para o Desenvolvimento (PNUD). Atlas do desenvolvimento humano no Brasil. Brasil [acesso em 13 mai 2015]. Disponível em: $<$ http://www.pnud.org.br/atlas/>.

16. Victora CG, Huttly SRA, Barros FC, Lombardi C, Vaughan JP. Maternal education in relation to early and late child health outcomes: Findings from a Brazilian cohort study. Soc Sci Med. 1992; 34: 899-905.

17. Benicio MHD'A, Monteiro CA. Tendência secular da doença diarréica na infância na cidade de São Paulo (19841996). Rev Saúde Pública. 2000; 34 (6): 83-90

18. França E, Souza JM, Guimarães MDC, Goulart EMA Colosimo E, Antunes CMF. Associação entre fatores sócioeconômicos e mortalidade infantil por diarreia, pneumonia e desnutrição em região metropolitana do Sudeste do Brasil: um estudo caso-controle. Cad Saúde Pública. 2001; 17 (6): 1437-47

19. Araújo MFM, Ferreira AB, Gondim KM, Chaves ES. A prevalência de diarreia em crianças não amamentadas ou com amamentação por tempo inferior a 6 meses. Ciênc Cuid Saúde. 2007; 6 (1): 76-84
20. WHO (World Health Organization). Medical Education: teaching medical students about diarrhoeal disease. Geneva; 1999.

21. Moraes LC, Silva GAP. Diarreia Aguda: o conhecimento materno sobre a doença reduz o número de hospitalizações nos menores de 2 anos? Rev Assoc Med Bras. 2004; 50: 276-81.

22. Joventino ES, Freitas LV, Vieira NFC, Aquino PS, Pinheiro AKB, Ximenes LB. Habilidades maternas para prevenção e manejo da diarreia infantil. Ciênc Enferm. 2013; 19 (2): 6776.

23. Joventino ES, Bezerra KC, Coutinho RG, Almeida PC, Oriá MOB, Ximenes LB. Condições sociodemograficas e sanitárias na auto-eficácia materna para prevenção da diarreia infantil. Rev Saúde Pública. 2013; 15: 542-54.

24. Clasen T, Schmidt WP, Rabie T, Riberts I, Cairncross S. Interventions to improve water quality for preventing diarrhoea: systematic review and meta-analysis. BMJ. 2007; 334 (7597): 782.

25. El-Gilany AH, Hammad S. Epidemiology of diarrhoeal diseases among children under age 5 years in Dakahlia, Egypt. East Mediterr Health J.2005; 11 (4): 762-75.

26. Abreu MVS, Oliveira JC, Andrade VDA, Meira AD. Proposta metodológica para o cálculo e análise espacial do IDH intraurbano de Viçosa - MG. Rev Bras Estud Popul. 2011; 28: 169-86

27. Oliveira T, Latorre MRDO. Tendências da internação e da mortalidade infantil por diarréia: Brasil, 1995 a 2005. Rev Saúde Pública. 2010; 44 (1): 102-11.

28. Meneguessi GM, Mossri RM, Segatto TCV, Reis PO. Morbimortalidade por doenças diarreicas agudas em crianças menores de 10 anos no Distrito Federal, Brasil, 2003 a 2012. Epidemiol Serv Saúde. 2015; 24 (4): 721-30.

29. Assis ASF, Valle DA, Antunes GR, Tibiriça SHC, Assis RMS, Leite JPG, Carvalho IP, Rosa e Silva ML. Epidemiologia das rotaviroses antes e após a introdução da vacina. J Pediatr. (Rio J.). 2013; 89 (5): 470-6.

Received on December 14, 2016

Final version presented on March 27, 2017

Approved on April 18, 2017 